\title{
Collectin Kidney 1 Plays an Important Role in Innate Immunity against Streptococcus pneumoniae Infection
}

\author{
Insu Hwang ${ }^{a}$ Kenichiro Mori ${ }^{a} \quad$ Katsuki Ohtani ${ }^{a}$ Yasuyuki Matsuda ${ }^{a}$ Nitai Roy ${ }^{a}$ \\ YounUck Kim $^{\text {b }}$ Yasuhiko Suzuki $^{\mathrm{a}, \mathrm{c}}$ Nobutaka Wakamiya ${ }^{\mathrm{a}}$ \\ aDepartment of Microbiology and Immunochemistry, Asahikawa Medical University, Asahikawa, Japan; \\ ${ }^{b}$ Department of BT Convergence Pharmaceutical Engineering, Sun Moon University, Asan, Republic of Korea; \\ 'Department of Bioresources, Research Center for Zoonosis Control, Hokkaido University, Sapporo, Japan
}

\author{
Keywords \\ Collectin $\cdot$ Complement $\cdot$ Innate immunity $\cdot$ Knockout \\ mice $\cdot$ Pneumonia
}

\begin{abstract}
Collectins are C-type lectins that are involved in innate immunity as pattern recognition molecules. Recently, collectin kidney 1 (CL-K1) has been discovered, and in vitro studies have shown that $\mathrm{CL}-\mathrm{K} 1$ binds to microbes and activates the lectin complement pathway. However, in vivo functions of $\mathrm{CL}-\mathrm{K} 1$ against microbes have not been elucidated. To investigate the biological functions of CL-K1, we generated CL-K1 knockout $\left(\mathrm{CL}-\mathrm{K}^{-/-}\right)$mice and then performed a Streptococcus pneumoniae infection analysis. First, we found that recombinant human $\mathrm{CL}-\mathrm{K} 1$ bound to $\mathrm{S}$. pneumoniae in a calcium-dependent manner, and induced complement activation. $\mathrm{CL}-\mathrm{K}^{-/-}$mice sera formed less $\mathrm{C} 3$ deposition on $\mathrm{S}$. pneumoniae. Furthermore, immunofluorescence analysis in the wild-type (WT) mice demonstrated that CL-K1 and C3 were localized on S. pneumoniae in infected lungs. $\mathrm{CL}-\mathrm{K}^{-1-}$ mice revealed decreased phagocytosis of $S$. pneumoniae. Consequently, less S. pneumoniae clearance was observed in their lungs. $\mathrm{CL}-\mathrm{K} 1^{-/-}$mice showed severe pulmonary inflam-
\end{abstract}

\section{KARGER}

(c) 2017 S. Karger AG, Basel

E-Mail karger@karger.com

www.karger.com/jin mation and weight loss in comparison with WT mice. Finally, the decreased clearance and severe pulmonary inflammation caused by S. pneumoniae infection might cause higher $\mathrm{CL}-\mathrm{K} 1^{-/-}$mice lethality. Our results suggest that $\mathrm{CL}-\mathrm{K} 1 \mathrm{might}$ play an important role in host protection against S. pneumoniae infection through the activation of the lectin complement pathway.

(c) 2017 S. Karger AG, Basel

\section{Introduction}

Innate immune responses are the first defense line against invasive pathogens and are based on the recognition of microbial carbohydrate patterns on the cell surface. Collectins are a family of C-type lectins that are involved in host defense as pattern recognition molecules. Collectins share a common structure that is composed of a collagen-like domain, $a$-helical neck domain, and carbohydrate recognition domain (CRD). Collectins are assembled into trimers and further organized into higher

I.H., K.M., and K.O. contributed equally to this work.
Dr. Nobutaka Wakamiya

Department of Microbiology and Immunochemistry, Asahikawa Medical University 2-1-1-1 Midorigaoka-Higashi

Asahikawa, Hokkaido 078-8510 (Japan)

E-Mail wakamiya@asahikawa-med.ac.jp 
oligomeric structures through the $\mathrm{N}$-terminal cysteinerich domain $[1,2]$.

Mannose-binding lectin (MBL) and surfactant protein A and D (SP-A, SP-D) were the first identified collectins. MBL is synthesized in the liver and expressed as a serum protein and makes a complex with MBL-associated serine proteases (MASPs) to activate the lectin complement pathway $[3,4]$. MBL binds to microbes as an opsonin for phagocytes via the collectin receptor, and also acts as a viral neutralization factor $[5,6]$. SP-A and SP-D are isolated from lung surfactant, and play important roles in host defense and lung homeostasis [7].

In the past decades, a number of studies have demonstrated that "novel collectin" collectin kidney 1 (CL-K1) plays a pivotal role in embryogenesis as well as in the innate immune system $[8,9]$. The interaction of CL-K1 with sugar ligands shows a high affinity with high-mannose oligosaccharide composed of an a1-2 linkage [10]. Tissue distribution of CL-K1 was examined using RT-PCR, immunofluorescence, and immunohistochemistry, revealing mRNA and protein expression in the kidney, adrenal glands, small intestine, lung, liver, and brain [11]. CL-K1 in the blood is thought to be produced in hepatocytes in the liver. The blood concentration of CL-K1 in a healthy Japanese population group and Danish group was 0.34 and $0.28 \mu \mathrm{g} / \mathrm{mL}[12,13]$, and the concentration did not vary depending on gender and age [12]. However, increased concentration of CL-K1 in plasma was reported from disseminated intravascular coagulation (DIC) patients compared to non-DIC patients. Also, the plasma CL-K1 level was higher in respiratory disease and coagulation disorders [14]. It seems that some diseases affect or are affected by the expression of CL-K1 and plasma CL-K1 concentrations. CL-K1 directly activates the lectin complement pathway on Candida albicans using MASP-2 [15] and interacts with MASP-1/-3 [16]. Very recently, heteromeric complexes of native CL-K1 and CL-L1 were found in the circulation plasma, which were designated as CL-LK [17].

Streptococcus pneumoniae (pneumococcus) is a major human pathogen that causes pneumonia, meningitis, febrile bacteremia, otitis media, sinusitis, and bronchitis. According to the World Health Organization, worldwide, over 800,000 children under 5 years of age die every year due to $S$. pneumoniae infections [18].

In this study, we elucidated CL-K1 recognition of microbes and its binding mechanisms in vitro. To investigate the functional role of CL-K1 in pulmonary infection against $S$. pneumoniae, we utilized $\mathrm{CL}-\mathrm{K}^{-/-}$mice and demonstrated that CL-K1 might play an important role in host defense against $S$. pneumoniae infection in these mice.

\section{Materials and Methods}

\section{Expression of Recombinant Human CL-K1}

Recombinant human CL-K1 (rhCL-K1) was prepared as described previously [12]. Briefly, a stable CHO cell line that expressed full-length human CL-K1 was cultured for 7 days in a serum-free condition. The culture supernatant was incubated with mannan-agarose (Sigma-Aldrich, Japan) in the presence of $5 \mathrm{~mm}$ $\mathrm{CaCl}_{2}$, and rhCL-K1 was eluted by $0.1 \mathrm{M}$ mannose/TBSC (Trisbuffered saline, $5 \mathrm{mM} \mathrm{CaCl}_{2}, 0.1 \mathrm{M}$ mannose). The eluted fraction was applied to PD-10 Desalting Column (GE Healthcare, Japan) to remove mannose just before using.

\section{Bacterial Strains and Culture Conditions}

S. pneumoniae serotype 2 D39 strain (NCTC 7466) was grown on sheep blood agar plates for $20 \mathrm{~h}$ in a $5 \% \mathrm{CO}_{2}$ incubator. S. pneumoniae was collected by sterilized cotton swabs, and were then resuspended in BHI (brain heart infusion) broth (Fluka, Japan). Escherichia coli serotype O6 (ATCC 25922) was grown in LuriaBertani broth (Becton Dickinson, Japan) until the $\mathrm{OD}_{600}$ measured 0.6. Bacteria were heat-inactivated at $95^{\circ} \mathrm{C}$ for $10 \mathrm{~min}$, then washed and resuspended by $0.1 \%$ BSA/PBS (phosphate-buffered saline, $0.1 \%$ bovine serum albumin). Live $S$. pneumoniae was not treated with heat inactivation. Bacterial suspension was aliquoted and stored at $-80^{\circ} \mathrm{C}$ until use. Zymosan was purchased from Molecular Probes (USA) and resuspended in the same buffer.

\section{CL-K1-Binding Assay and Binding Inhibition Assay}

An rhCL-K1- and native CL-K1-binding assay were mainly performed in a $1.5-\mathrm{mL}$ centrifuge tube. rhCL-K1 (final concentration, $0,0.25,2.5,25 \mu \mathrm{g} / \mathrm{mL})$ and normal human serum $(0,0.3,1,3$, $10,30 \%)$ as native CL-K1 were incubated with $10 \mu \mathrm{L}$ of heat-inactivated bacteria $\left(\mathrm{OD}_{600}=12\right)$ or zymosan $(180 \mu \mathrm{g} / \mathrm{mL})$ in $180 \mu \mathrm{L}$ of $3 \%$ BSA/TBSTC (TBSC, $0.1 \%$ Tween $20,3 \%$ BSA) at $37^{\circ} \mathrm{C}$ for 1 h. For the inhibition assay, $15 \mathrm{~mm}$ ethylenediaminetetraacetic acid (EDTA, Wako, Japan), 0.1 M mannose (Nacalai Tasque, Japan), or $10 \mu \mathrm{g} / \mathrm{mL}$ Poly A or Poly I (Sigma-Aldrich, Japan) were added. After washing 3 times with TBSTC, rabbit anti-human CL-K1 polyclonal antibody [12] was added and incubated for $1 \mathrm{~h}$ at $37^{\circ} \mathrm{C}$, followed by incubation with a HRP-conjugated secondary antibody and TMB Microwell Peroxidase substrate. The enzymatic reaction was stopped by adding $1 \mathrm{M} \mathrm{H}_{3} \mathrm{PO}_{4}$, and the tubes were centrifuged at $15,000 \mathrm{rpm}$ for $5 \mathrm{~min}$ at $4^{\circ} \mathrm{C}$ to spin down microbes. Supernatants were transferred to a microtiter well plate and the enzymatic reaction was measured at $450 \mathrm{~nm}$ using a microtiter plate reader. In the another binding analysis by the pull-down method, microbes treated with rhCL-K1 (final concentration, $25 \mu \mathrm{g} / \mathrm{mL}$ ) were washed 5 times with TBSTC and resuspended in a protein sample buffer containing $\beta$-mercaptoethanol, then heated at $95^{\circ} \mathrm{C}$ for $5 \mathrm{~min}$. The rhCL-K1 levels that bound to microbes and control rhCL-K1 were visualized by Western blotting with the same antiCL-K1 polyclonal antibody.

\section{Phagocytosis Assay}

An in vitro phagocytosis assay was performed using a Vybrant Phagocytosis Assay Kit (Molecular Probes, USA) according to the manufacturer's instructions. First, FITC-labeled S. pneumoniae was prepared. Briefly, freshly cultured S. pneumoniae was heatinactivated at $95^{\circ} \mathrm{C}$ for $10 \mathrm{~min}$ and suspended in $0.1 \mathrm{M}$ sodium bicarbonate (pH 9.0). S. pneumoniae was labeled with $10 \mu \mathrm{g} / \mathrm{mL}$ of 
FITC (Molecular Probes, USA) for $1 \mathrm{~h}$ in the dark. After washing with $0.1 \% \mathrm{BSA} / \mathrm{PBS}$, it was aliquoted and stored at $-80^{\circ} \mathrm{C}$ until use. $1 \times 10^{6}$ cells $/ \mathrm{mL}$ of mouse macrophage cell line J774A.1 was prepared and $100 \mu \mathrm{L}$ of cell suspension was plated onto 96-well plates and incubated for $24 \mathrm{~h}$ at $37^{\circ} \mathrm{C}$ in a $5 \% \mathrm{CO}_{2}$ incubator. FITC-labeled E. coli (Molecular Probes, USA) and FITC-labeled S. pneumoniae were preincubated with or without of rhCL-K1 $(25 \mu \mathrm{g} /$ $\mathrm{mL}$ ), and added to J774A.1 cells followed by incubation for $2 \mathrm{~h}$ at $37^{\circ} \mathrm{C}$ in a $5 \% \mathrm{CO}_{2}$ incubator. After removing the bacterial suspension, $100 \mu \mathrm{L}$ of trypan blue was added for quenching of the cell surface-bound FITC-labeled S. pneumoniae. This was followed by measuring fluorescence intensity using a fluorescence plate reader ( $480 \mathrm{~nm}$ excitation, $\sim 520 \mathrm{~nm}$ emissions).

\section{Mice}

$\mathrm{CL}-\mathrm{K}^{-/-}$mice were generated as described elsewhere [Mori et al., manuscript in preparation]. Genotyping of mice was performed using PCR with the following 3 primers, ON8053: $5^{\prime} \mathrm{CT}$ GCTTTCAAGCCATGAATCTCTGTTTGTA, ON8056: 5' CAGCAGGGACAGGAAAGCCAGGCTAATCAG, ON6093: 5' CTTGGGTGGAGAGGCTATTCGGCTATGACT. CL-K1 ${ }^{+/-}$mice were backcrossed into a C57BL/6J background more than 8 generations to obtain a pure genetic background. All mice were housed in specific pathogen-free conditions with an artificial 12-h dark-light cycle, with free access to standard food and drinking water. All experiments were carried out in accordance with the rules and guidelines of the Animal Experiment Committee of Asahikawa Medical University.

\section{Deposition of Mouse C3 by in vitro Assay}

Mice sera C3 deposition was assayed using ELISA. Nunc-Immuno $^{\mathrm{TM}}$ MicroWell ${ }^{\mathrm{TM}}$ 96-Well Plates (Thermo Scientific, Japan) were coated with $10 \mu \mathrm{g} / \mathrm{mL}$ of zymosan or heat-inactivated $S$. pneumoniae $\mathrm{D} 39\left(\mathrm{OD}_{600}=0.6\right)$ in a coating buffer $\left(15 \mathrm{mM} \mathrm{Na}_{2} \mathrm{CO}_{3}, 35\right.$ $\mathrm{mM} \mathrm{NaHCO}, \mathrm{pH} 9.6)$ and incubated overnight at $4^{\circ} \mathrm{C}$. After washing with TBSTC, wells were blocked by TBS containing $0.1 \%$ human serum albumin for $1 \mathrm{~h}$ at $37^{\circ} \mathrm{C}$. Serum was collected from 10 individual wild-type (WT) and CL- $\mathrm{K}^{-/-}$male mice. $1 \%$ mice sera in barbital buffer $\left(4 \mathrm{mM} \mathrm{C}_{8} \mathrm{H}_{11} \mathrm{~N}_{2} \mathrm{O}_{3} \mathrm{Na}, 145 \mathrm{mM} \mathrm{NaCl}, 2 \mathrm{mM}\right.$ $\mathrm{CaCl}_{2}, 1 \mathrm{mM} \mathrm{MgCl}_{2}$ ) were incubated for $90 \mathrm{~min}$ at $37^{\circ} \mathrm{C}$. After washing, wells were incubated with rabbit anti-human $\mathrm{C} 3 \mathrm{c}$ polyclonal antibody (Dako, Japan) and donkey anti-rabbit IgG HRP conjugate (Merck Millipore, Japan). Next, $100 \mu \mathrm{L}$ of Sure Blue ${ }^{\mathrm{TM}}$ TMB Microwell Peroxidase substrate (KPL, USA) was added and incubated for $10 \mathrm{~min}$ at room temperature. The reaction was stopped by adding $1 \mathrm{M} \mathrm{H}_{3} \mathrm{PO}_{4}$, and the enzymatic reaction was measured at $\mathrm{OD}_{450 \mathrm{~nm}}$ using a microtiter plate reader.

\section{In vitro C3 Deposition Assay}

An rhCL-K1 C3 deposition assay was performed in 1.5-mL centrifuge tubes. Ten microliters of $S$. pneumoniae $\left(\mathrm{OD}_{600}=12\right)$ was incubated with rhCL-K1 (final concentration, 0, 0.25, 2.5, $25 \mu \mathrm{g} / \mathrm{mL}$ ) in $100 \mu \mathrm{L}$ of TBSTC at $37^{\circ} \mathrm{C}$ for $1 \mathrm{~h}$. S. pneumoniae was collected by centrifugation and washed 3 times with TBSTC. Human serum was passed through HiTrap Protein G HP columns (GE Healthcare, Japan) to inactivate the classical complement pathway against $S$. pneumoniae caused by anti-S. pneumoniae antibodies, and the passed serum was incubated with $\mathrm{N}$-acetyl-glucosamine-agarose (GlcNAcagarose, Sigma-Aldrich, Japan) to inactivate the lectin complement pathway caused by ficolin. One hundred microliters of the above serum (1\%) was added to S. pneumoniae and incubated for $90 \mathrm{~min}$ at $37^{\circ} \mathrm{C}$. After washing with TBSTC, rabbit anti-human C3c polyclonal antibody was added and incubated for $1 \mathrm{~h}$ at $37^{\circ} \mathrm{C}$, followed by incubation with a secondary antibody and TMB Microwell Peroxidase substrate. The reaction was stopped by adding $1 \mathrm{M} \mathrm{H}_{3} \mathrm{PO}_{4}$, and the tubes were centrifuged at $15,000 \mathrm{rpm}$ for $5 \mathrm{~min}$ at $4{ }^{\circ} \mathrm{C}$ to spin down $S$. pneumoniae. The supernatant was transferred to microtiter well plates and the enzymatic reaction was measured at $450 \mathrm{~nm}$ using a microtiter plate reader.

\section{Infection}

Male mice (12-15 weeks old) were anesthetized with pentobarbital, and $20 \mu \mathrm{L}$ of BHI broth containing $0,1 \times 10^{4}, 1 \times 10^{6}$, or $1 \times$ $10^{7} \mathrm{CFU}$ (colony-forming units) of S. pneumoniae D39 was administered by pipetting into the nostrils. To determine the infection dose, a preliminary experiment was performed using WT mice. $S$. pneumoniae $\mathrm{CFU}$ in $\mathrm{BHI}$ broth were calculated as $\mathrm{OD}_{600}=38$, which equals $1 \times 10^{6} \mathrm{CFU} / \mu \mathrm{L}$. For the survival investigation, visible clinical symptoms and body weight change were monitored for 10 days. The survival of the animal was assessed every $24 \mathrm{~h}$.

\section{Lung CFU Calculation}

To examine the bacteria clearance of the lung, mice were infected intranasally with $1 \times 10^{6} \mathrm{CFU}$ of $S$. pneumoniae. At $48 \mathrm{~h}$ after infection, the mice were killed by cervical dislocation, and the lungs were collected into centrifugation tubes. Then the lungs were weighed and saline 4 times the volume of each lung was added. The lungs were homogenized and $100 \mu \mathrm{L}$ of homogenate was mixed with $900 \mu \mathrm{L}$ of sterilized saline. Serial dilution $\left(10^{-6}\right)$ was made with each lung sample, and $100-\mu \mathrm{L}$ aliquots of each dilution sample were plated onto $5 \%$ sheep blood agar plates. The plates were incubated for $20 \mathrm{~h}$ at $37^{\circ} \mathrm{C}$ in $5 \% \mathrm{CO}_{2}$, and the number of CFU was counted.

\section{Histology}

Mice were infected intranasally with $1 \times 10^{4} \mathrm{CFU}$ of $S$. pneumoniae. At $48 \mathrm{~h}$ after infection, the mice were killed and the lungs were removed and fixed in a $10 \%$ formalin neutral buffer for $24 \mathrm{~h}$. Four-micrometer paraffin-embedded sections were cut and placed onto microscope slides and stained with hematoxylin and eosin (HE). This was followed by a pathologist-blinded analysis of lung inflammation. Inflammation was scored using the following parameters: interstitial inflammation, intra-alveolar inflammation, edema, endotheliitis, bronchitis, thrombi formation, and pleuritis $[19,20]$. Each parameter was graded on a scale of $0-3$ as follows: 0 , absent; 1 , mild; 2 , moderate; and 3 , severe. The total lung inflammation score was expressed as the sum of the scores for each parameter, so the maximum score was 21 .

\section{Immunohistochemistry}

To detect CL-K1, S. pneumoniae, and C3 in infected mice lungs, WT and CL- $\mathrm{K}^{-/-}$male mice were intranasally infected with $1 \times$ $10^{6} \mathrm{CFU}$ of $S$. pneumoniae. At 6 and $24 \mathrm{~h}$ after infection, the mice were killed and the lungs were removed and fixed in a $10 \%$ formalin neutral buffer solution for $24 \mathrm{~h}$. Four-micrometer paraffin embedded sections were cut and placed onto microscope slides, and deparaffinized by a series of methanol baths.

To improve immunoreactivity, sections were treated with an antigen retrieval buffer (Citrate Buffer pH 6.0, Dako, Japan), and heated in a microwave. After washing with PBS, sections were blocked for endogenous avidin and biotin by incubating with avi- 

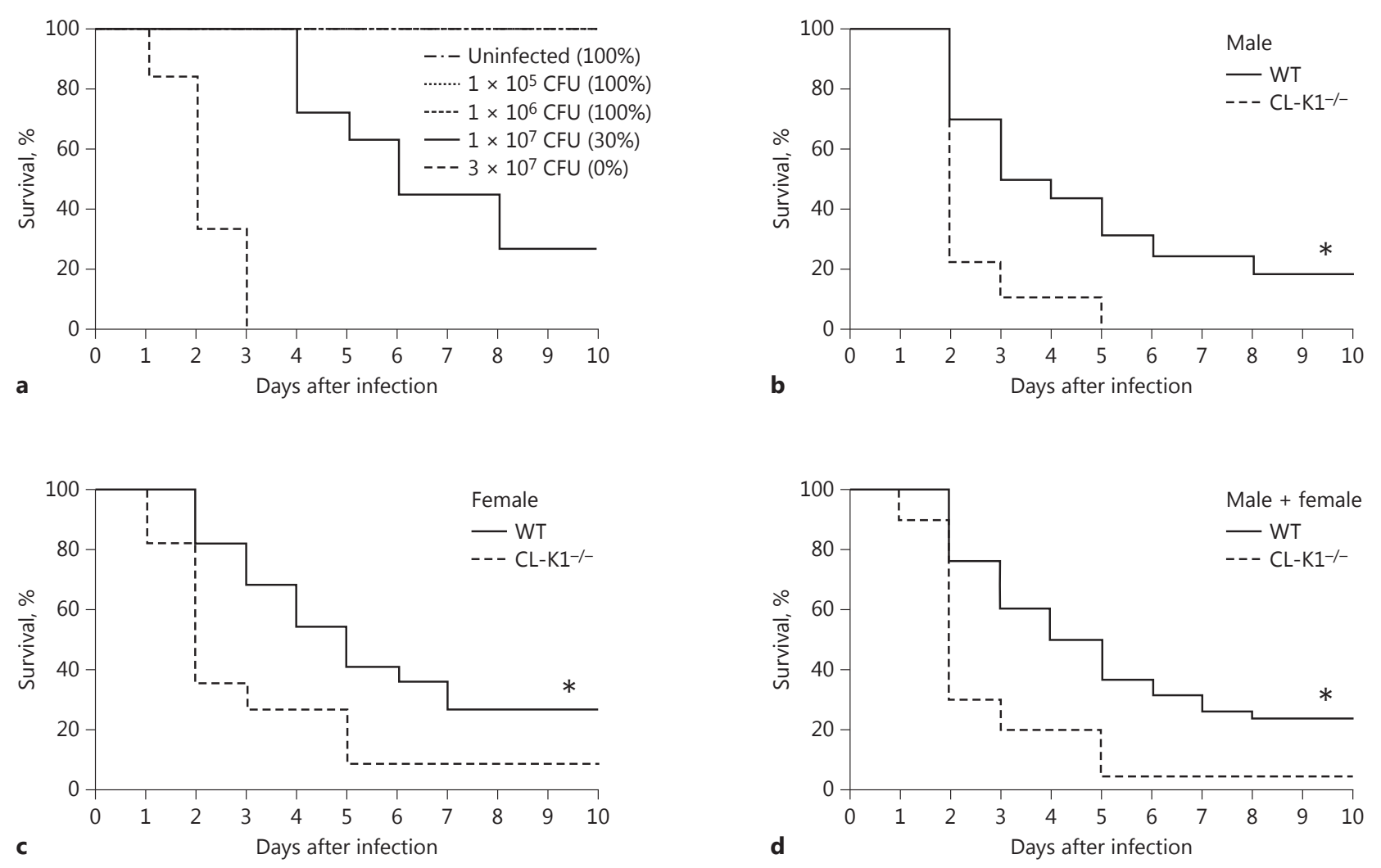

Fig. 1. CL-K1-1- mice showed increased susceptibility to $S$. pneumoniae infection. a The first experiment was performed to identify the $\mathrm{LD}_{50}$ of WT mice. WT mice were intranasally infected with $0,1 \times 10^{5}, 1 \times 10^{6}, 1 \times 10^{7}$, or $3 \times 10^{7} \mathrm{CFU}$ of $S$. pneumoniae $(n=6$ in each group), and consequently the $\mathrm{LD}_{50}$ was calculated by their survival rates. b-d WT and CL- $\mathrm{K}^{-/-}$mice were intranasally infected with $1 \times 10^{7} \mathrm{CFU}$ of $S$. pneumoniae and the survival rates

din solution for $15 \mathrm{~min}$ followed by biotin solution for $15 \mathrm{~min}$ (Avidin/Biotin-Blocking System, Dako, Japan). Then sections were blocked with Block Ace (Dainippon Pharmaceutical, Japan) for $1 \mathrm{~h}$ at room temperature followed by incubation with either affinity-purified rabbit anti-CL-K1 polyclonal antibody [11], rabbit anti-human C3c polyclonal antibody, or control IgG for $20 \mathrm{~h}$ at $4^{\circ} \mathrm{C}$. After primary antibody incubation, these sections were incubated with Alexa Fluor 488-conjugated goat anti-rabbit IgG $(\mathrm{H}+\mathrm{L})$ secondary antibody (Life Technologies, USA) for $1 \mathrm{~h}$ at room temperature. For S. pneumoniae, the above slides were incubated with biotin-conjugated rabbit anti-S. pneumoniae polyclonal antibody (ViroStat, USA) for $20 \mathrm{~h}$ at $4^{\circ} \mathrm{C}$. After washing, slides were incubated with Alexa Fluor 555 streptavidin (Life Technologies, USA) for $1 \mathrm{~h}$ at room temperature followed by mounting in SlowFade Gold Antifade Reagent (Molecular Probes, USA). Serial sections were stained with $\mathrm{HE}$ to visualize lung tissue. The fluorescence images were obtained using a confocal laser-scanning microscope (FV1000; Olympus Optical, Japan). were calculated. CL-K1 ${ }^{-/-}$male mice $(n=9)$ showed increased mortality compared with WT mice $(n=11) . p=0.0163$ for the logrank test $(\mathbf{b})$. CL-K1 $1^{-/}$female mice $(n=11)$ also showed increased mortality compared with WT mice $(n=22) . p=0.0258$ for the logrank test $(\mathbf{c})$. Total CL-K1 ${ }^{-1-}$ mice $(n=20)$ showed increased susceptibility compared with WT mice $(n=33) . p=0.0012$ for the log-rank test $(\mathbf{d}) .{ }^{*} p<0.05$.

\section{In vivo Phagocytosis Assay}

WT and CL- $\mathrm{K}^{-1-}$ mice were infected intranasally with $1 \times 10^{6}$ $\mathrm{CFU}$ of $S$. pneumoniae. At $6 \mathrm{~h}$ after infection, the mice were killed and the lungs were removed and fixed in a $10 \%$ formalin neutral buffer for $24 \mathrm{~h}$. Four-micrometer paraffin-embedded sections were cut and placed onto microscope slides and stained with biotin-conjugated rabbit anti-S. pneumoniae antibody followed by AlexaFluor 555 streptavidin. Over 100 cells were counted on several microscopic fields and the phagocytic index was expressed as the average number of AlexaFluor 555-stained S. pneumoniae per single phagocyte.

\section{Statistical Analysis}

Statistical analysis was performed using the Student $t$ test included in the JMP statistics software package (Version 7, SAS, Japan). Statistical analysis of the survival rate was performed using a log-rank test. $p<0.05$ was considered statistically significant. 


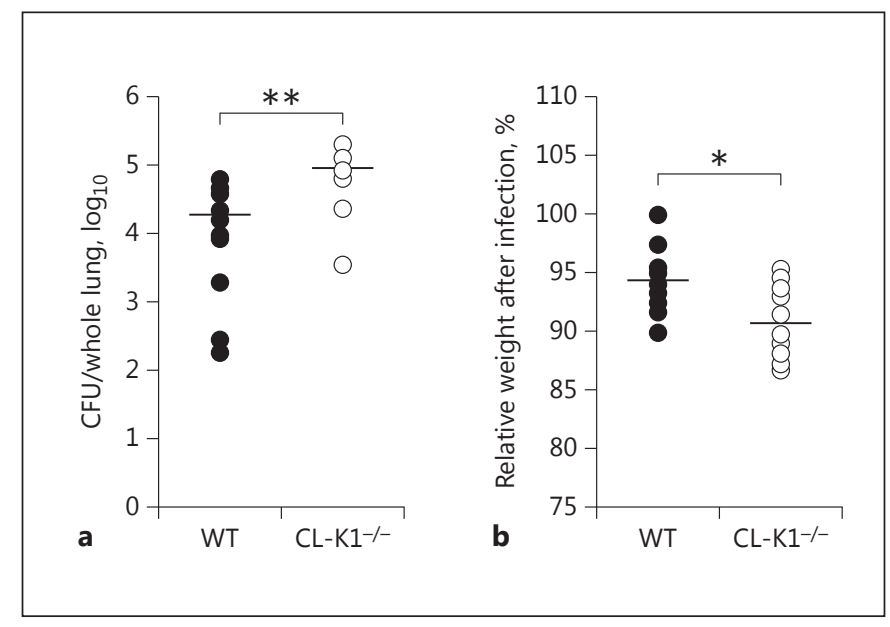

Fig. 2. Clearance of $S$. pneumoniae in WT and CL-K1 ${ }^{-1-}$ mice lungs at $48 \mathrm{~h}$ after infection. WT $(n=11)$ and CL-K1 ${ }^{-/-}(n=10)$ male mice were intranasally infected with $1 \times 10^{6} \mathrm{CFU}$ of $S$. pneumoniae. a At $48 \mathrm{~h}$ after infection, CL-K1 $1^{-/-}$mice lungs showed a significantly greater number of $S$. pneumoniae compared with WT mice lungs. $\mathbf{b}$ The body weights of CL- $\mathrm{K}^{-/-}$mice were lower than those of WT mice at $48 \mathrm{~h}$ after infection. Each dot represents results of an individual mouse and horizontal bars represent the average of each group. ${ }^{*} p<0.05{ }^{* *} p<0.005$.

\section{Results}

CL-K1 $1^{-/-}$Mice Are More Susceptible to S. pneumoniae Infection

Male WT mice were infected with $0,1 \times 10^{5}, 1 \times 10^{6}$, $1 \times 10^{7}$, or $3 \times 10^{7} \mathrm{CFU}$ of $S$. pneumoniae (Fig. 1a). All mice infected with $0,1 \times 10^{5}$, or $1 \times 10^{6} \mathrm{CFU}$ survived until 10 days after infection. In contrast, all mice infected with $3 \times 10^{7} \mathrm{CFU}$ died within 3 days after infection. $1 \times 10^{7} \mathrm{CFU}$-infected mice began to die at 4 days after infection and $30 \%$ of the mice survived over the entire experimental period (10 days). Based on these results, we carried out a survival analysis using $1 \times 10^{7} \mathrm{CFU}$ of $S$. pneumoniae. Figure $1 \mathrm{~b}-\mathrm{d}$ demonstrates that the mortality of CL- $\mathrm{K}^{-/-}$mice was significantly higher than that of WT mice. CL- $\mathrm{K}^{-/-}$male mice began to die at 2 days after infection, and all mice died within 5 days after infection. WT male mice also began to die at 2 days after infection, with other WT mice dying at different times throughout the entire experimental period. Twenty percent of the mice were still alive at 10 days after infection (Fig. 1b, mean survival time, WT, $115.44 \pm 18.48 \mathrm{~h}$; CL$\mathrm{K} 1^{-/-}, 58.56 \pm 7.92 \mathrm{~h}, p=0.0163$ for the log-rank test). We also observed a significantly longer survival time of WT female compared to that of CL- $\mathrm{K}^{-/-}$female mice
(Fig. 1c, mean survival time, WT, $135.12 \pm 15.60 \mathrm{~h}$; CL$\mathrm{K} 1^{-/-}, 76.32 \pm 18.96 \mathrm{~h}, p=0.0258$ for the log-rank test). Finally, the total survival rate demonstrated that CL$\mathrm{K}^{-/-}$mice exhibited increased susceptibility compared to WT mice (Fig. 1d, mean survival time, WT, $126.72 \pm$ $11.76 \mathrm{~h} ; \mathrm{CL}-\mathrm{K} 1^{-/-}, 68.40 \pm 11.04 \mathrm{~h}, p=0.0012$ for the logrank test).

\section{Clearance of S. pneumoniae Is Decreased in $\mathrm{CL}-\mathrm{K}^{-/-}$} Mice

We examined murine lung CFU and body weights at $48 \mathrm{~h}$ after $1 \times 10^{6} \mathrm{CFU}$ of $S$. pneumoniae inoculation. Greater numbers of viable $S$. pneumoniae were observed in CL- $\mathrm{K}^{-/-}$mice lungs compared with those in WT mice lungs (Fig. 2a, WT, 20,425 \pm 20,650; CL-K1 $1^{-/-}, 90,616 \pm$ $59,395, p<0.005)$. The body weight of WT mice decreased $6 \%$ at $48 \mathrm{~h}$ after infection and weights of CL$\mathrm{K} 1^{-1-}$ mice decreased $9 \%$ at the same time (Fig. $2 \mathrm{~b}, p<$ $0.05)$. These results suggest that the lower clearance of $S$. pneumoniae in CL- $\mathrm{K}^{-1-}$ mice might cause severe harm to the mice.

\section{CL-K1 $1^{-/-}$Mice Revealed More Severe Pulmonary}

Inflammation after $\mathrm{S}$. pneumoniae Infection

First we confirmed whether CL- $\mathrm{K}^{-/-}$mice have the pulmonary anomaly or dysfunction feature or not. CL$\mathrm{K} 1^{-/-}$mice showed no difference in lung histologic feature compared with WT mice (online suppl. Fig. 1; see www.karger.com/doi/10.1159/000453316 for all online suppl. material). To determine the role of CL-K1 in pulmonary inflammation, we infected WT and CL- $\mathrm{K}^{-/-}$ mice with $1 \times 10^{4} \mathrm{CFU}$ of $S$. pneumoniae, and analyzed their lung histology by $\mathrm{HE}$ staining at $48 \mathrm{~h}$ after infection. Severe lung inflammation was observed in CL$\mathrm{K} 1^{-/-}$mice compared with that in WT mice (Fig. 3a, total lung inflammation score: WT, $5.37 \pm 1.26$; CL-K1 ${ }^{-1-}$, $7.67 \pm 1.42, p<0.005)$. In detail, CL-K1 ${ }^{-1-}$ mice showed a higher score for interstitial inflammation, intra-alveolar inflammation, endotheliitis, and bronchitis (fig. 3b, $p<0.005)$. Next, we performed sequential and histological lung analyses $(0,6$, and $24 \mathrm{~h}$ post infection) in WT and CL-K1 $1^{-1-}$ mice infected with $1 \times 10^{6} \mathrm{CFU}$ of $S$. pneumoniae. At $6 \mathrm{~h}$ after infection, WT and $\mathrm{CL}-\mathrm{K}^{-/-}$mice lungs showed similar levels of inflammation. However, at $24 \mathrm{~h}$ after infection, CL-K1 ${ }^{-/-}$mice lungs showed more severe inflammation compared to WT mice lungs (Fig. 4, HE). CL-K1 immunofluorescence staining in WT mice lungs demonstrated that a high expression of $\mathrm{CL}-\mathrm{K} 1 \mathrm{was}$ observed at $6 \mathrm{~h}$ after infection and remained until $24 \mathrm{~h}$ after infection in bronchial and alveolar epi- 


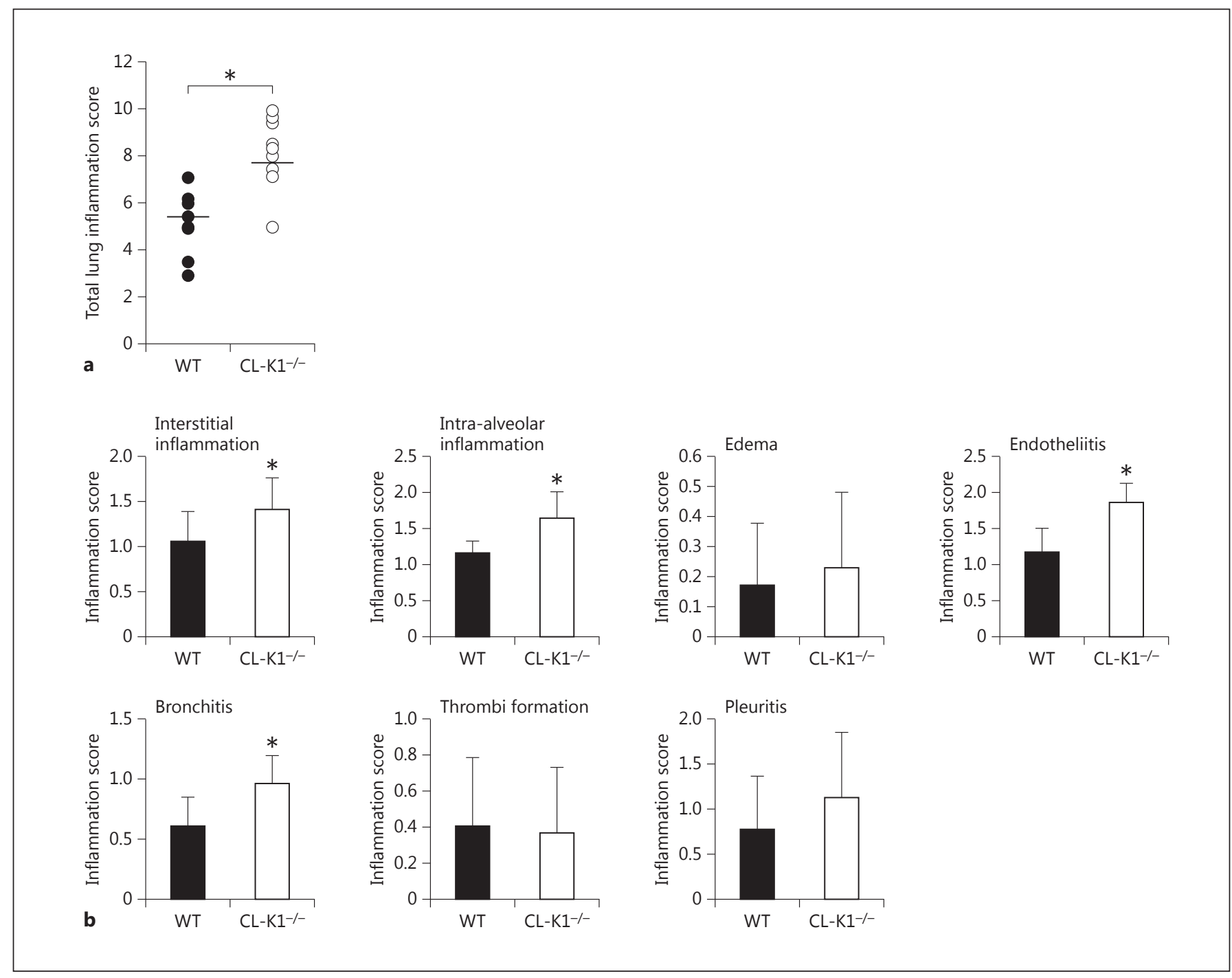

Fig. 3. CL-K1 $1^{-/-}$mice revealed severe pulmonary inflammation after S. pneumoniae infection. Lung histology was scored using lung inflammation analysis (see Materials and Methods). Each parameter was graded on a scale of $0-3$. CL-K1 ${ }^{-/-}(n=9)$ mice showed more severe pulmonary inflammation at $48 \mathrm{~h}$ after infection com-

thelial cells, although the staining of $\mathrm{CL}-\mathrm{K}^{-/-}$mice lungs was negative (Fig. 4, CL-K1). In S. pneumoniae staining, a large number of $S$. pneumoniae was observed in lungs of CL- $\mathrm{K}^{-/-}$mice at 6 and $24 \mathrm{~h}$ after infection, although the numbers decreased in the lungs of WT mice at $24 \mathrm{~h}$ after infection (Fig. 4, S. pneumoniae). We already observed that same CFU $\left(1 \times 10^{6}\right)$-infected CL$\mathrm{K}^{-/-}$mice at $48 \mathrm{~h}$ after infection showed a greater number of bacteria and more severe weight loss compared with WT mice (Fig. 2a, b). pared to WT mice $(n=11)$. a Total lung inflammation score. Each dot represents the result of an individual mouse and horizontal bars represent the average of each group. $\mathbf{b}$ The data in each parameter represent means $\pm \mathrm{SD} .{ }^{*} p<0.005$.

CL-K1 Directly Interacts with S. pneumoniae and Activates the Lectin Pathway

To determine the binding ability of CL-K1 to S. pneumoniae serotype $2 \mathrm{D} 39$ strain, we incubated S. pneumoniae for $1 \mathrm{~h}$ with normal human serum (final concentration of $0,0.3,1,3,10,30 \%)$ and rhCL-K1 $(0,0.25,2.5,25 \mu \mathrm{g} /$ $\mathrm{mL})$. The bound CL-K1 was visualized by an ELISA system (Fig. 5a, b) and Western blotting (Fig. 5c, d). The ELISA system using rhCL-K1 and normal human serum demonstrated that both bindings between bacteria and 


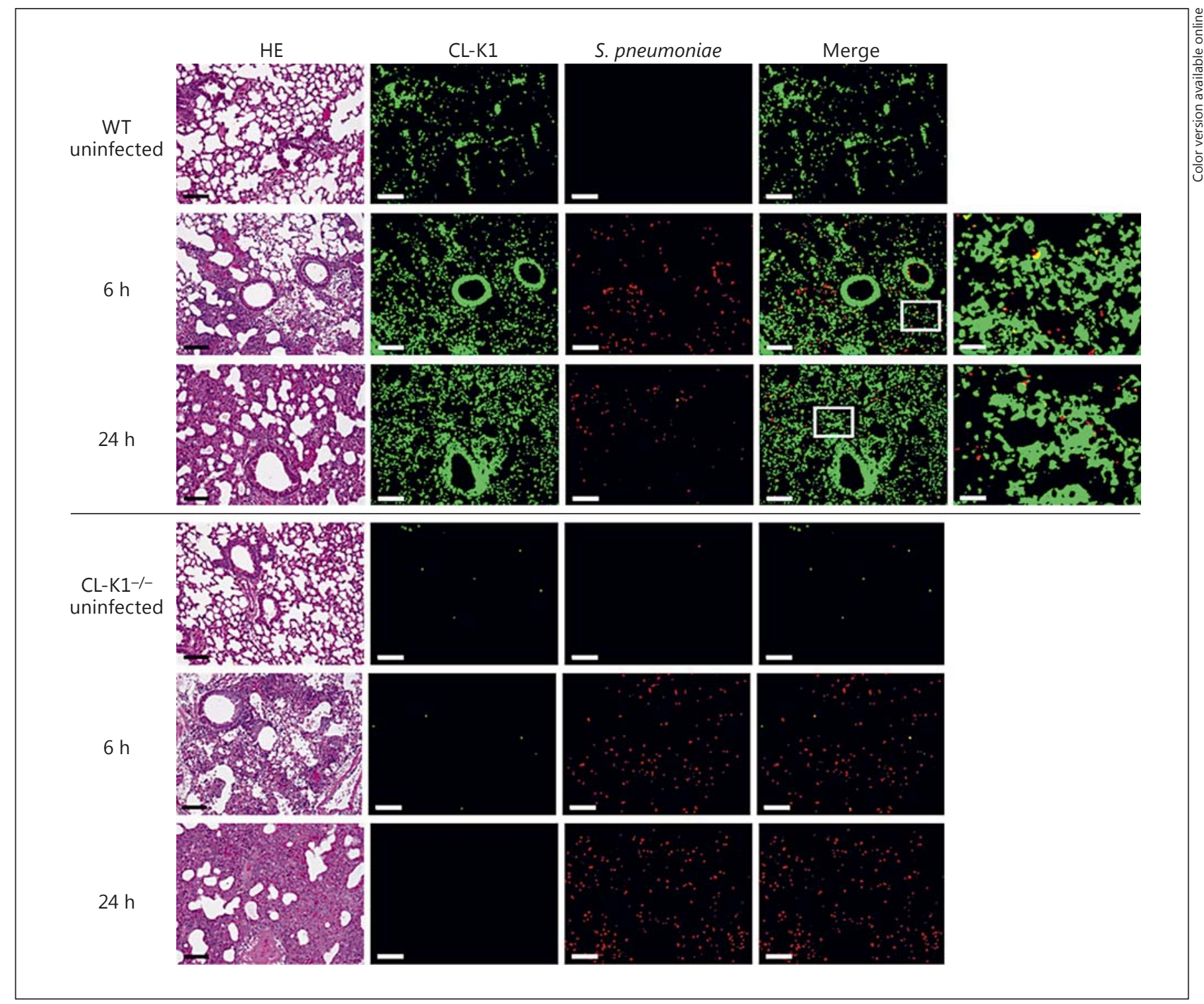

Fig. 4. Histological features of the lungs of WT and CL- $\mathrm{K}^{-/-}$mice. WT and CL- $\mathrm{K}^{-1-}$ male mice were intranasally infected with $1 \times$ $10^{6} \mathrm{CFU}$ of $S$. pneumoniae. At 6 and $24 \mathrm{~h}$ after infection, histological features of $S$. pneumoniae-infected mice lungs were compared by HE, CL-K1 (green, color in online version only), and S. pneumoniae (red) staining. At $6 \mathrm{~h}$ after infection, increased CL-K1 ex- pression was observed in WT mice. CL-K1 was colocalized with $S$. pneumoniae. Merged images $(1,000 \times)$ show higher magnification of the boxed region. In CL- $\mathrm{K}^{-/-}$mice, no CL-K1 expression was observed at any time point. HE staining also indicates more severe inflammation in CL-K1 $1^{-/-}$mice. Scale bars, $100 \mu \mathrm{m}$; merge $(1,000 \times), 20 \mu \mathrm{m}$.
rhCL-K1 or native CL-K1 were dose dependent and were found in the physiological condition concentration of $0.25 \mu \mathrm{g} / \mathrm{mL}$. We also confirmed the similar binding activity in viable and heat-inactivated bacteria (online suppl. Fig. 2). Next we examined the binding ability of rhCL-K1 to gram-negative bacteria E. coli serotype O6 (S type LPS), and fungus cell wall extract zymosan. It was found that rhCL-K1 interacted with E. coli and zymosan (online sup-

CL-K1 Is Related to the Resistance to

S. pneumoniae Infection pl. Fig. 3). We found that rhMBL only recognized and interacted with zymosan, while no binding activity was observed in S. pneumoniae and E. coli in the same assay system (data not shown). These results are consistent with previous studies that have demonstrated the interaction of MBL with microbes [21-23].

CL-K1 is considered to interact with specific complex carbohydrates in a calcium-dependent manner via the 

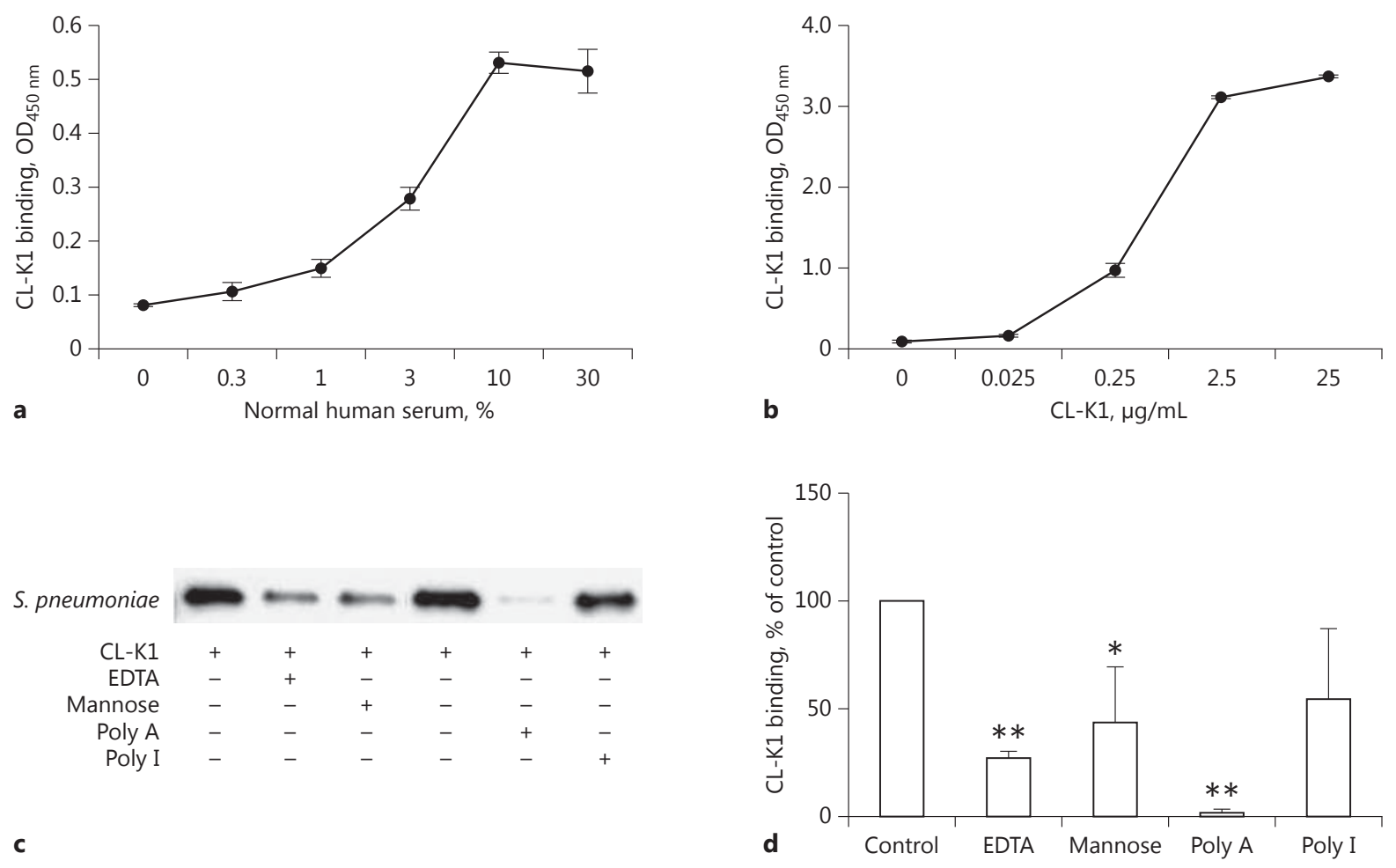

Fig. 5. CL-K1 interacts with $S$. pneumoniae. a, b Normal human serum $(0-30 \%)(\mathbf{a})$ or rhCL-K1 $(0-25 \mu \mathrm{g} / \mathrm{mL})(\mathbf{b})$ was incubated with heat-inactivated $S$. pneumoniae. CL-K1 binding was developed by rabbit anti-human CL-K1 PoAb. Both native CL-K1 and rhCL-K1 were dose dependently bound to S. pneumoniae and rhCL-K1 binding was observed at physiological concentration of CL-K1 $(0.25 \mu \mathrm{g} / \mathrm{mL})$. Data represent means \pm SD of triplicate ex-

Table 1. rhCL-K1-binding rate (\%) of E. coli, zymosan, and $S$. pneumoniae

\begin{tabular}{llllll}
\hline Microbes & \multicolumn{5}{l}{ CL-K1 binding, \% of control } \\
\cline { 2 - 6 } & $\begin{array}{l}\text { con- } \\
\text { trol }\end{array}$ & $\begin{array}{l}\text { EDTA } \\
(15 \mathrm{mM})\end{array}$ & $\begin{array}{l}\text { Mannose } \\
(0.1 \mathrm{M})\end{array}$ & $\begin{array}{l}\text { Poly A } \\
(10 \mu \mathrm{g} / \mathrm{mL})\end{array}$ & $\begin{array}{l}\text { Poly I } \\
(10 \mu \mathrm{g} / \mathrm{mL})\end{array}$ \\
\hline E. coli & 100 & $113 \pm 71$ & $41 \pm 26^{*}$ & $62 \pm 27$ & $229 \pm 110$ \\
Zymosan & 100 & $29 \pm 6^{* *}$ & $19 \pm 11^{* *}$ & $93 \pm 10$ & $134 \pm 53$ \\
S. pneumoniae & 100 & $26 \pm 4^{* *}$ & $43 \pm 26^{*}$ & $1 \pm 2^{* *}$ & $54 \pm 33$ \\
\hline
\end{tabular}

Data represent means \pm SD of 3 independent experiments. ${ }^{*} p<0.05$; ** $p<0.005$. periments. c, d For the inhibition assay, binding reactions were performed with $15 \mathrm{~mm}$ EDTA, $0.1 \mathrm{M}$ mannose, or $10 \mu \mathrm{g} / \mathrm{mL}$ of Poly A, or Poly I. Using the Image J program, Western blotting bands were quantified and the subsequent binding rate (\%) was calculated by comparing with the control. Binding was inhibited by EDTA, mannose, or Poly A. Data represent means \pm SD of 3 independent experiments. ${ }^{*} p<0.05 ;{ }^{* *} p<0.005$.

CRD $[8,10]$. In this study, we performed the inhibition analysis using several inhibitors to identify the binding specificities of CL-K1 against microbes. We found that EDTA and mannose inhibited partially the binding of rhCL-K1 to S. pneumoniae (Fig. 5c, d; Table 1, $26 \pm 4 \%$, $p<0.005$ and $43 \pm 26 \%, p<0.05$, respectively). These results indicate that CL-K1 recognizes carbohydrate patterns on S. pneumoniae cell surfaces in a calcium-dependent manner via the CRD. Interestingly, positive charge inhibitor Poly A also strongly inhibited the binding to S. pneumoniae $(1 \pm 2 \%, p<0.005)$.

Another binding inhibition assay revealed that CL$\mathrm{K} 1$ interacted with $E$. coli in a calcium-independent manner (online suppl. Fig. 3). EDTA did not inhibit the binding to E. coli. However, mannose inhibited the 
Fig. 6. CL-K1 activates the complement pathway on S. pneumoniae. a Heat-inactivated S. pneumoniae was preincubated with rhCL-K1 $(0-25 \mu \mathrm{g} / \mathrm{mL})$, followed by incubation with IgG and ficolin-depleted $1 \%$ human serum. C3 deposition was developed by rabbit anti-human $\mathrm{C} 3 \mathrm{c}$ PoAb. rhCL-K1 before incubation augmented C3 deposition on $S$. pneumoniae. Data represent means \pm SD of 3 independent experiments. ${ }^{*} p<0.05$. ns, not significant. b Heat-inactivated $S$. pneumoniae was incubated with $1 \%$ WT $(n=10)$ or CL-K1 ${ }^{-/-}$ $(n=10)$ mice sera. C3 deposition was developed in the same way, and in $\mathrm{CL}-\mathrm{K}^{-/-}$ mice sera it was significantly lower than in WT mice sera. Each dot represents the result of an individual mouse. ${ }^{*} p<0.05$.
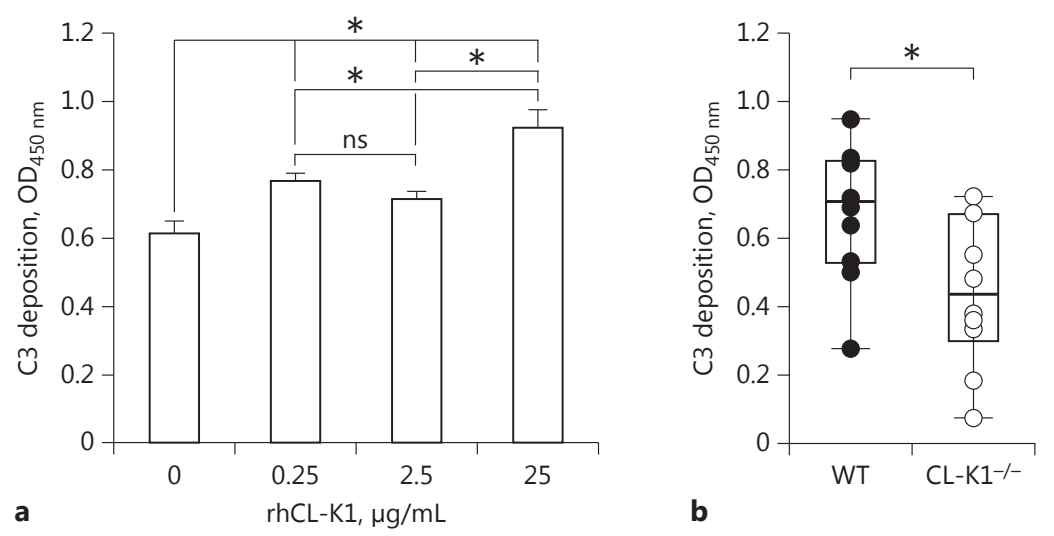

binding to E. coli. On the other hand, in case of the fungus, EDTA and mannose significantly inhibited the binding to zymosan (online suppl. Fig. 3). These results suggest that CL-K1 binds to zymosan in a calcium-dependent manner via the CRD like MBL. Our in vitro binding analyses suggest that rhCL-K1 might be able to interact directly with several microbes in a calcium- and charge-dependent manner.

To investigate the complement activation by CL-K1 on S. pneumoniae, C3 deposition analysis was performed using rhCL-K1. Human serum was passed through a protein $\mathrm{G}$ column to remove anti-S. pneumoniae antibodies [24]. To prevent lectin pathway activation, the above serum was treated with GlcNAc agarose beads to eliminate ficolin [25]. Analysis using double-depleted serum demonstrated that C3 deposition significantly increased following before incubation of rhCL-K1 (Fig. 6a). These results indicate that $\mathrm{CL}-\mathrm{K} 1$ directly binds to $\mathrm{S}$. pneumoniae and activates the complement system. Next, we examined the complement activity of CL-K1 $1^{-/}$mice sera against $S$. pneumoniae. Our results showed that $\mathrm{C} 3$ deposition by $\mathrm{CL}-\mathrm{K}^{-1-}$ mice sera was significantly lower than that in WT mice sera (Fig. 6b, WT, $0.668 \pm 0.192$; CL-K1 ${ }^{-/-}$, $0.445 \pm 0.216, p<0.05)$. These results also suggest that CL-K1 might activate the complement pathway in the mouse system.

rhCL-K1 Exhibits Opsonic Activity against E. coli but

Not against $\mathrm{S}$. pneumoniae

To assess the opsonic activity of rhCL-K1 against $S$. pneumoniae, we carried out a phagocytosis analysis.
FITC-labeled E. coli or S. pneumoniae were preincubated with or without rhCL-K1 $(25 \mu \mathrm{g} / \mathrm{mL})$, and then incubated with the mouse macrophage cell line J774A.1. As shown in Figure $7 \mathrm{a}$, we could observe a significant increase in the phagocytosis of E. coli K12 after preincubation of rhCL-K1. However, preincubation of rhCL-K1 did not influence $S$. pneumoniae phagocytosis (Fig. 7b). These data indicate that rhCL-K1 might act as an opsonin against $E$. coli, but not act against $S$. pneumoniae in vitro.

\section{CL-K1 Interacts with S. pneumoniae in WT Mice}

Lungs and $\mathrm{CL}-\mathrm{K1}^{-/-}$Mice Showed Decreased

Phagocytosis of S. pneumoniae

To elucidate the interaction between CL-K1 and $S$. pneumoniae in murine lungs, WT and $\mathrm{CL}-\mathrm{K}^{-/-}$mice were intranasally infected with $1 \times 10^{6} \mathrm{CFU}$ of $S$. pneumoniae. In the early phase of infection, we observed $S$. pneumoniae colocalized with CL-K1 and counted the number of $S$. pneumoniae engulfed by phagocytes in WT $(n=2)$ or CL-K1 ${ }^{-/-}(n=2)$ mice lungs (Fig. $\left.7 \mathrm{c}, \mathrm{d}\right)$. The numbers of $S$. pneumoniae particles phagocytosed by one phagocyte were significantly lower in $\mathrm{CL}-\mathrm{K}^{-/-}$mice compared to those in WT mice $(4.11 \pm 2.07$ in WT mice and $3.03 \pm 1.75$ in CL-K1 ${ }^{-/-}$mice, $\left.p<0.001\right)$. C3 depositions were also observed on engulfed S. pneumoniae, although we could not perform the double staining by anti$\mathrm{CL}-\mathrm{K} 1$ and anti-C3 polyclonal $\mathrm{Ab}$. These data suggest that CL-K1 might be able to activate the complement pathway in murine lungs, thereby augmenting the phagocytosis of S. pneumoniae. 
Fig. 7. CL-K1 exhibits opsonic activity against $S$. pneumoniae in vivo. Mouse macrophage J774A.1 cells were incubated with FITC-labeled E. coli (a) or FITC-labeled S. pneumoniae (b) which were preincubated with or without rhCL-K1 $(25 \mu \mathrm{g} / \mathrm{mL})$. Phagocytosed microbes were measured by fluorescence intensity. Preincubation of rhCL-K1 augmented phagocytosis of $E$. coli, but not of $S$. pneumoniae. Representative data are shown, and data represent means \pm SD of triplicate well values. $* p<$ 0.05. c, $\mathbf{d} \mathrm{WT}$ and CL-K1 $1^{-/-}$male mice were intranasally infected with $1 \times 10^{6} \mathrm{CFU}$ of $S$. pneumoniae. At $6 \mathrm{~h}$ after infection, serial lung sections were stained with anti-CL-K1 $\mathrm{Ab}$, anti-S. pneumoniae $\mathrm{Ab}$ or anti-C3c Ab, anti-S. pneumoniae Ab combination. The phagocytosis level (phagocytic index) was measured by calculating the average number of $S$. pneumoniae in a single phagocyte. CL-K1 $1^{-/-}$mice $(n=2)$ showed significantly reduced phagocytosis of $S$. pneumoniae compared with WT mice $(n=2)(\mathbf{c})$. Data represent means $\pm \mathrm{SD}$. ${ }^{*} p<0.001$. In the infected WT mice lung, CL-K1 (green, upper; color in online version only) or C3 (green, bottom) was colocalized with phagocytosed S. pneumoniae (red). Merged images (yellow) show colocalization of CL$\mathrm{K} 1$ and S. pneumoniae (upper) or C3 and $S$. pneumoniae (bottom) (d). Scale bars, $5 \mu \mathrm{m}$.

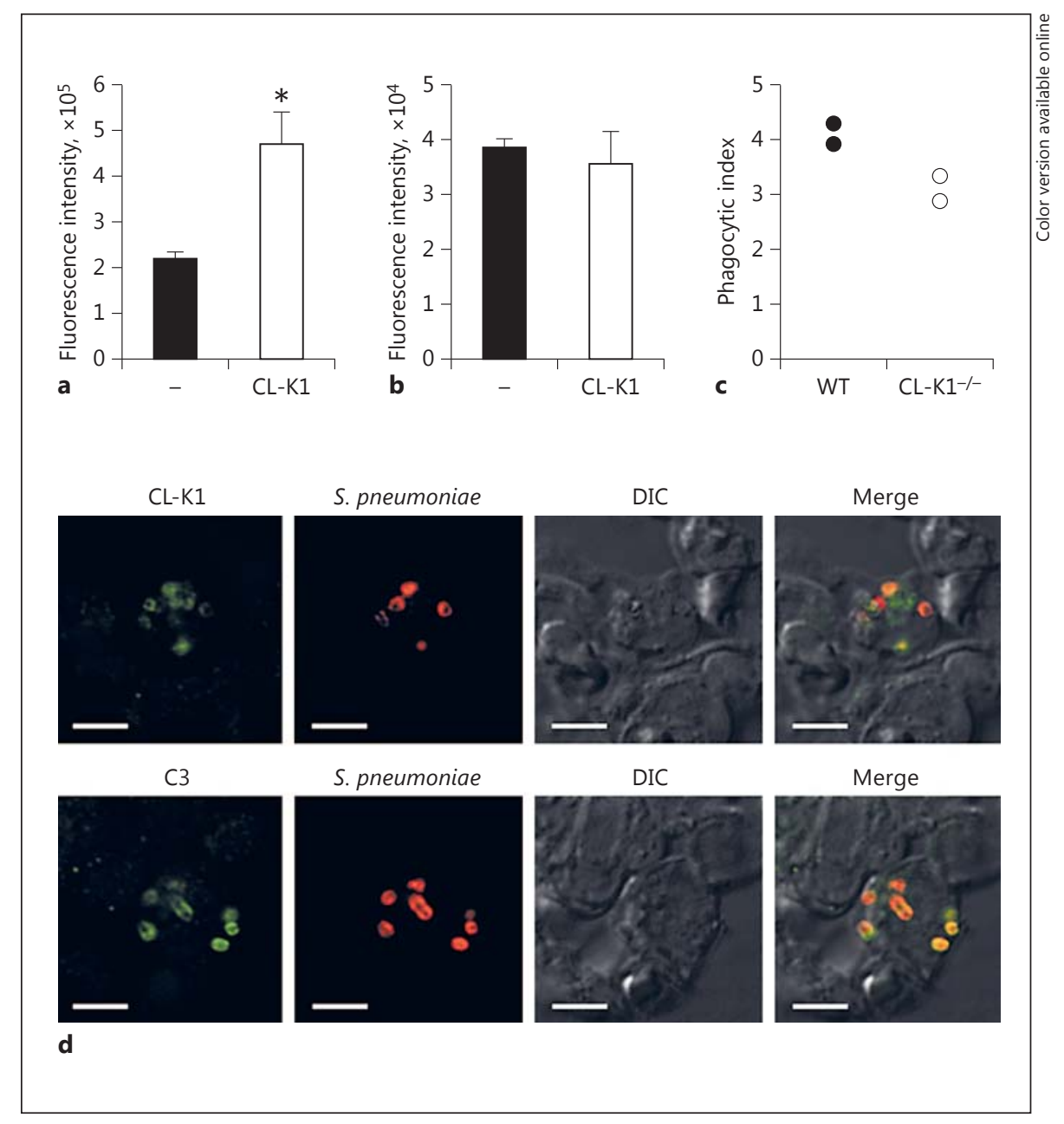

\section{Discussion}

Collectins and ficolins generally play a role in opsonization, complement activation, and the elimination of microbes against invading pathogens $[1,2,25]$. Among these biological functions, complement activation is considered to be particularly important in protecting the body from infectious diseases $[25,26]$. Furthermore, it was found that complement factors were present in the lung which might activate complement system during bacterial infection $[25,27]$. The components of C1q, factor $\mathrm{B}, \mathrm{C} 2, \mathrm{C} 3, \mathrm{C} 4, \mathrm{C} 5$, and $\mathrm{C} 6$ in humans, and C3, C5, and factor $\mathrm{B}$ in mice and rats were observed in bronchoalveolar lavage [27]. However, it has not been shown that CL$\mathrm{K} 1$ is present in bronchoalveolar lavage.

In this study, we investigated the host defense roles of CL-K1 against $S$. pneumoniae with in vitro and in vivo analyses. Recent studies indicate that CL-K1 in human and mouse serum might interact with $S$. pneumoniae [28]. However, direct interaction between CL-K1 and $S$. pneumoniae has not been demonstrated clearly. Here we found that rhCL-K1 directly interacted with S. pneumoni$a e$ in a charge-dependent manner in addition to being due to calcium-dependent lectin activity (Fig. 5c, d; Table 1 ). We consider that CL-K1 has a positively charged region in its structure and that it can additionally interact with negatively charged S. pneumoniae. Recently, CL-K1 has been shown to bind to DNA ligands in a charge-dependent manner, but not in a calcium-dependent manner [29]. Two well-known collectins, MBL and SP-D, can also bind DNA by their CRDs and collagen-like regions, but not strongly [30,31].

Online supplementary Figure 3 and Table 1 show that the binding mechanism of rhCL-K1 to E. coli and zymosan was different from that of $S$. pneumoniae. The reason is because the interactions between rhCL-K1 to $E$. coli 
and zymosan were not inhibited by any charged ligands. We demonstrated that rhCL-K1 interacted with E. coli due to calcium-independent lectin activity and that it interacted with zymosan due to calcium-dependent lectin activity, respectively, via CRD. These results suggest that CL-K1 might utilize 2 unique domains of the CRD-binding site and the collagen-like region to recognize and interact with various microbes, although further study using a deletion mutant of the collagen-like region or CRD is needed.

In previous studies, sandwich ELISA using human EDTA plasma showed the interaction between CL-K1 and MASPs, and rhCL-K1 bound to C. albicans and induced the deposition of $\mathrm{C} 4 \mathrm{~b}, \mathrm{C} 3 \mathrm{~b}$, and MAC on the surface of C. albicans $[15,16]$. Our C3 deposition analysis demonstrated that CL-K1 might cause the activation of the lectin complement pathway on the surface of $S$. pneumoniae (Fig. 6a). It is well known that microbes opsonized by complement are easily recognized by phagocytes, which express complement receptors on their surface, and consequently lead to increased phagocytosis [26]. In in vitro analysis, rhCL-K1 could increase phagocytosis of E. coli, but it did not enhance the phagocytosis of S. pneumoniae (Fig. 7a, b). In murine experiments, C3 deposition on $\mathrm{S}$. pneumoniae by $\mathrm{CL}-\mathrm{K}^{-/-}$mice sera was lower than WT mice sera, and CL- $\mathrm{K}^{-/-}$mice showed a greater number of $S$. pneumoniae in the lungs compared to WT mice after inoculation (Fig. 6b, 2a). These results suggest that CL-K1 in animal models might be able to affect complement activation and reduce the number of microbes. The detailed mechanism of the biological function in CL-K1 in vivo needs to be resolved in the future.

In the murine infection study, we observed that $S$. pneumoniae infection of CL-K1 $1^{-/-}$mice caused more severe inflammation in their lungs compared to WT mice (Fig. 3). A previous study reported that MASP-2 $2^{-/-}$mice infected with $S$. pneumoniae exhibited increased proinflammatory cytokines (e.g., TNFa and IL-6) and these mRNA expressions led to severe inflammation in the lungs [28]. Recently, it was reported that neutrophil extracellular trap formation plays an important role in inflammation after microbe infection. Neutrophils can catch DNA from cells and broken microbes and regulate the inflammation [32,33]. The presence of neutrophil extracellular trap formation has been demonstrated in various inflammatory lung diseases including asthma, cystic fibrosis, and microbe infections. It has been shown that CL-K1 binds just as strongly to nucleotides as DNA compared to polysaccharide [29]. It indicates that CL-K1 might be able to bind these DNA during/after pulmonary microbial infection and might be related to neutrophil extracellular trap-related inflammation due to complement activation.

$\mathrm{WT}$ and $\mathrm{CL}-\mathrm{K1}^{-/-}$mice showed almost the same amount of $S$. pneumoniae in the lungs at $6 \mathrm{~h}$ after infection. However, at $24 \mathrm{~h}$ after infection, WT mice demonstrated lower amounts of $S$. pneumoniae than CL- $\mathrm{K}^{-/-}$ mice (Fig. 4). CL- $1^{-/-}$mice showed larger amounts of $S$. pneumoniae even at $48 \mathrm{~h}$ after infection compared with WT mice (Fig. 2a). We believe that the reduced survival rate of $\mathrm{CL}-\mathrm{K}^{-/-}$mice after $S$. pneumoniae infection might be due to bacteria proliferation and severe pulmonary inflammation (Fig. 1b-d).

Mutations in both CL-K1 and MASP-3 coding genes is associated with $3 \mathrm{MC}$ (Mingarelli, Malpuech, Michels, and Carnevale) syndrome. This congenital disorder is characterized by facial dysmorphism, cleft palate, craniosynostosis, learning disabilities, and genital, limb, and vesicorenal anomalies [9]. Three separate mutations in CL-K1 are associated with $3 \mathrm{MC}$ syndrome. In transient transfection studies, these CL-K1 mutant proteins were not secreted into the medium [10]. This fact indicates that the secretion of CL-K1 might play a crucial role not only in innate immunity, but also in fetal development. Our results in murine infection experiments suggest that $3 \mathrm{MC}$ syndrome patients might show innate immunity dysfunction, although this has not been reported yet.

In summary, CL-K1 binds directly to $S$. pneumoniae and increases opsonophagocytosis. CL-K1 might also activate the lectin complement pathway, and consequently reduce numbers of $S$. pneumoniae in murine-infected lungs. CL-K1 deficiency shows increased lethality from $S$. pneumoniae infections. Finally, our study demonstrated the host-protecting role of CL-K1 against S. pneumoniae infection.

\section{Acknowledgement}

This work was supported by grants from JSPS KAKENHI (Grant No. 22390113, 26293124) and from the Northern Advancement Center for Science \& Technology (Sapporo, Japan). This work was also supported by grants from the Smoking Research Foundation and the Mizutani Foundation (120136) for Glycoscience.

\section{Disclosure Statement}

The authors declare that they have no financial conflicts of interest. 


\section{References}

1 Sastry K, Ezekowitz RA: Collectins: pattern recognition molecules involved in first line host defense. Curr Opin Immunol 1993;5:5966.

2 Holmskov U, Jensenius JC: Structure and function of collectins: humoral C-type lectins with collagenous regions. Behring Inst Mitt 1993;93:224-235.

3 Kawasaki N, Kawasaki T, Yamashina I: Isolation and characterization of a mannan-binding protein from human serum. J. Biochem 1983;94:937-947.

4 Matsushita M, Fujita T: Activation of the classical complement pathway by mannose-binding protein in association with a novel C1slike serine protease. J Exp Med 1992;176: 1497-1502.

5 Malhotra R, Thiel S, Reid KBM, Sim RB: Human leukocyte $\mathrm{C} 1 \mathrm{q}$ receptor binds other soluble proteins with collagen domains. J Exp Med 1990;172:955-959.

6 Kase T, Suzuki Y, Kawai T, Sakamoto T, Ohtani K, Eda S, Maeda A, Okuno Y, Wakamiya $\mathrm{N}$ : Human mannan-binding lectin inhibits the infection of influenza A virus without complement. Immunology 1999;97:385392.

7 Kuroki Y, Takahashi M, Nishitani C: Pulmonary collectins in innate immunity of the lung. Cell Microbiol 2007;9:1871-1879.

8 Keshi H, Sakamoto T, Kawai T, Ohtani K, Katoh T, Jang S, Motomura W, Yoshizaki T, Fukuda M, Koyama S, Fukuzawa J, Fukuoh A, Yoshida I, Suzuki Y, Wakamiya N: Identification and characterization of a novel human collectin CL-K1. Microbiol Immunol 2006 50:1001-1013.

9 Rooryck C, Diaz-Font A, Osborn DPS, Chabchoub E, Hernandez-Hernandez V, Shamseldin H, Kenny J, Waters A, Jenkins D, Kaissi AA, Leal GF, Dallapiccola B, Peeters H, Alkuraya FS, Beales P: Mutation in lectin complement pathway genes COLLEC11 and MASP1 cause 3MC syndrome. Nat Genet 2011;43:197-203.

10 Girija UV, Furze CM, Gingras AR, Yoshizaki T, Ohtani K, Marshall JE, Wallis AK, Schwaeble WJ, El-Mezgueldi M, Mitchell DA, Moody PCE, Wakamiya N, Wallis R: Molecular basis of sugar recognition by collecitn-K1 and the effects of mutations associated with $3 \mathrm{MC}$ syndrome. BMC Biol 2015;13:27.

11 Motomura W, Yoshizaki T, Ohtani K, Okumura T, Fukuda M, Fukuzawa J, Mori K, Jang S, Nomura N, Yoshida I, Suzuki Y, Kohgo Y, Wakamiya N: Immunolocalization of a novel collectin CL-K1 in murine tissues. J Histochem Cytochem 2008;56:243-252.

12 Yoshizaki T, Ohtani K, Motomura W, Jang S, Mori K, Kitamoto N, Yoshida I, Suzuki Y, Wakamiya N: Comparison of human blood concentrations of collectin kidney 1 and man- nan-binding lectin. J Biochem 2012;151:5764.

13 Selman L, Henriksen ML, Brandt J, Palarasah Y, Waters A, Beales PL, Holmskov U, Jørgensen TJ, Nielsen C, Skjodt K, Hansen S: An enzyme-linked immunosorbent assay (ELISA) for quantification of human collectin 11 (CL-11, CL-K1). J Immunol Methods 2012; 31:182-188.

14 Takahashi K, Ohtani K, Larvie M, Moyo P, Chigweshe L, Van Cott EM, Wakamiya N: Elevated plasma CL-K1 level is associated with a risk of developing disseminated intravascular coagulation (DIC). J Thromb Thrombolysis 2014;38:331-338.

15 Ma YJ, Skjoedt MO, Garred P: Collectin-11/ MASP complex formation triggers activation of the lectin complement pathway - the fifth lectin pathway initiation complex. J Innate Immun 2013;5:242-250.

16 Hansen S, Selman L, Palaniyar N, Ziegler K, Brandt J, Kliem A, Jonasson M, Skjoedt M, Nielsen O, Hartshorn K, Jorgensen TJD, Skjodt K, Holmskov U: Collectin 11 (CL-11, CL-K1) is a MASP-1/3-associated plasma collectin with microbial-binding activity. J Immunol 2010;185:6096-6104.

17 Henriksen ML, Brandt J, Andrieu JP, Nielsen C, Jensen PH, Holmskov U, Jorgensen TJ, Palarasah Y, Thielens NM, Hansen S: Heteromeric complexes of native collectin kidney 1 and collectin liver 1 are found in the circulation with MASPs and activate the complement system. J Immunol 2013;191:6117-6127.

18 Jeong D, Jeong E, Seo J, Heo S, Choi Y: Difference in resistance to Streptococcus pneumoniae infection in mice. Lab Anim Res 2011;27: 91-98.

19 Boelen A, Kwakkel J, Wieland CW, St Germain DL, Fliers E, Hernandez A: Impaired bacterial clearance in type 3 deiodinase-deficient mice infected with Streptococcus pneumoniae. Endocrinology 2009;150:1984-1990.

20 Schabbauer G, Matt U, Gunzl P, Warszawska J, Furtner T, Hainzl E, Elbau I, Mesteri I, Doninger B, Binder RB, Knapp S: Myeloid PTEN promotes inflammation but impairs bactericidal activities during murine pneumococcal pneumonia. J Immunol 2010;185:468-476.

21 Krarup A, Sorensen UBS, Matsushita M, Jensenius JC, Thiel S: Effect of capsulation of opportunistic pathogenic bacteria on binding of the pattern recognition molecules mannanbinding lectin, $\mathrm{L}$-ficolin, and $\mathrm{H}$-ficolin. Infect Immun 2005;73:1052-1060.

22 Brouwer N, Dolman KM, Van Houdt M, Sta M, Roos D, Kuijpers TW: Mannose-binding lectin $(\mathrm{MBL})$ facilitates opsonophagocytosis of yeasts but not of bacteria despite $\mathrm{MBL}$ binding. J Immunol 2008; 180:4124-4132.

23 Van Asbeck EC, Hoepelman AIM, Scharringa J, Herpers BL, Verhoef J: Mannose binding lectin plays a crucial role in innate immunity against yeast by enhanced complement activation and enhanced uptake of polymorphonuclear cells. BMC Microbiol 2008;8:229.

24 Brown JS, Hussel T, Gilliland SM, Holden DW, Paton JC, Ehrenstein MR, Walport MJ, Botto M: The classical pathway is the dominant complement pathway required for innated immunity to Streptococcus pneumoniae infection in mice. Proc Natl Acad Sci USA 2002;99:16969-16974.

25 Endo Y, Takahashi M, Iwaki D, Ishida Y, Nakazawa N, Kodama T, Matsuzaka T, Kanno K, Liu Y, Tsuchiya K, Kawamura I, Ikawa M, Waguri S, Wada I, Matsushita M, Shwaeble WJ, Fujita T: Mice deficient in ficolin, a lectin complement pathway recognition molecule, are susceptible to Streptococcus pneumoniae infection. J Immunol 2012;189:5860-5866.

26 Beltrame $\mathrm{MH}$, Boldt ABW, Catarino SJ, Mendes HC, Boschmann SE, Goeldner I, Messias-Reason I: MBL-associated serine proteases (MASPs) and infectious diseases. Mol Immunol 2015;67:85-100.

27 Bolger MS, Ross DS, Jiang H, Frank MM, Ghio AJ, Schwartz DA, Wright JR: Complement levels and activity in the normal and LPS-injured lung. Am J Physiol Lung Cell Mol Physiol 2007;292:748-759.

28 Ali YM, Lynch NJ, Haleem KS, Fujita T, Endo Y, Hansen S, Holmskov U, Takahashi K, Stahl GL, Dudler T, Girija UV, Wallis RW, Kadioglu A, Stover CM, Andrew PW, Schwaeble WJ: The lectin pathway of complement activation is a critical component of the innate immune response to pneumococcal infection. PLoS Pathog 2012;8:e1002793.

29 Henriksen ML, Brandt J, Lyer SSC, Thielens NM, Hansen S: Characterization of the interaction between collectin 11 (CL-11, CL-K1) and nucleic acids. Mol Immunol 2013;56: 757-767.

30 Hakansson K, Reid KB: Collectin structure: a review. Protein Sci 2000;9:1607-1617.

31 Palaniyar N, Nadesalingam J, Clark H, Shih MJ, Dodds AW, Reid KB: Nucleic acid is a novel ligand for innate, immune pattern recognition collectins surfactant proteins A and $\mathrm{D}$ and mannose-binding lectin. J Biol Chem 2004;279:32728-32736.

32 Knight JS, Carmona-Rivera C, Kaplan MJ: Proteins derived from neutrophil extracellular traps may serve as self-antigens and mediate organ damage in autoimmune diseases. Front Immunol 2012;3:380.

33 Grabcanovic-Musija F, Obermayer A, Stoiber W, Krautgartner WD, Steinbacher P, Winterberg N, Bathke AC, Klappacher M, Studnicka M: Neutrophil extracellular trap (NET) formation characterises stable and exacerbated COPD and correlates with airflow limitation. Respir Res 2015;16:59. 